Article

\title{
An Approach to Identify the Suitable Plant Location for Miscanthus-Based Ethanol Industry: A Case Study in Ontario, Canada
}

\section{Poritosh Roy ${ }^{1, *}$, Animesh Dutta ${ }^{1, *}$ and Bill Deen ${ }^{2}$}

1 School of Engineering, University of Guelph, Guelph, ON N1G 2W1, Canada

2 Department of Plant Agriculture, University of Guelph, Guelph, ON N1G 2W1, Canada; E-Mail: bdeen@uogeulph.ca

* Authors to whom correspondence should be addressed;

E-Mails: poritosh@uoguelph.ca (P.R.); adutta@uoguelph.ca (A.D.);

Tel.: +1-519-824-4120 (ext. 52441) (P.R. \& A.D.); Fax: +1-519-836-0227 (P.R. \& A.D.).

Academic Editor: Robert Lundmark

Received: 26 June 2015 / Accepted: 18 August 2015 / Published: 28 August 2015

\begin{abstract}
The life cycle (LC) of ethanol extracted from Miscanthus has been evaluated to identify the potential location for the Miscanthus-based ethanol industry in Ontario, Canada to mitigate greenhouse gas (GHG) emissions and minimize the production cost of ethanol. Four scenarios are established considering the land classes, land use, and cropping patterns in Ontario, Canada. The net energy consumption, emissions, and cost of ethanol are observed to be dependent on the processing plant location and scenarios. The net energy consumption, emissions, and cost vary from $12.9 \mathrm{MJ} / \mathrm{L}$ to $13.4 \mathrm{MJ} / \mathrm{L}, 0.79 \$ / \mathrm{L}$ to $0.84 \$ / \mathrm{L}$, and $0.45 \mathrm{~kg}-\mathrm{CO}_{2} \mathrm{e} / \mathrm{L}$ to $1.32 \mathrm{~kg}-\mathrm{CO}_{2} \mathrm{e} / \mathrm{L}$, respectively, which are reliant on the scenarios. Eastern Ontario has emerged as the best option. This study reveals that Miscanthus is a potential feedstock for the ethanol industries in Ontario, even if it is cultivated on marginal land. This study also highlights the contribution of energy crops (Miscanthus) to avoid the potential technical and economic constraints of lignocellulosic biomass for the renewable energy industry. Miscanthus may help avoid competition with food crops for prime land (higher quality land that is suitable for food crops), avoid the food versus fuel debate, help meet the ethanol demand, and achieve the GHG emissions abatement target of Canada.
\end{abstract}

Keywords: Miscanthus; ethanol; plant location; Ontario; greenhouse gas (GHG) emission; production cost 


\section{Introduction}

Liquid biofuels are identified as an alternative to fossil fuels, especially for transportation. The transportation sector in Canada accounts for about $25 \%$ of the nation's energy use and the major part of this energy comes from fossil fuels [1]. Fuel producers and importers in Canada are required to have at least $5 \%$ renewable fuel content in the distillate that is produced or imported [2]. However, ethanol has contributed only $1.7 \%$ of total transportation energy in 2010 [1], portraying the extensive demand for ethanol. The Government of Canada also offers $\$ 0.10 / \mathrm{L}$ and $\$ 0.26 / \mathrm{L}$ operating incentive for ethanol and biodiesel, respectively, for up to seven consecutive years [3], which drives the interest on liquid biofuels. Ethanol produced from food or feed grains compete with food or feed, and contributes to higher food prices [4-6]. Consequently, the ethanol production from lignocellulosic biomass has been emphasized to avoid any competition with food or feed crops $[7,8]$.

The potential of lignocellulosic biomass is enormous $[9,10]$. The global production potential for biomass production is noted to be $4500 \mathrm{EJ}$ [10] while transport energy demand is only about $90 \mathrm{EJ}$ [11]. The woody or lignocellulosic biomass production potential of the degraded or abandoned or surplus land is reported to be about $50 \mathrm{EJ}$ [12]. The amount of biomass that can be used for the ethanol industry differs among regions because of ecological, technical, and economic factors [9,13]. The potential biomass sources in Canada include municipal solid waste, forestry by-products, energy crops and agricultural residues. The technical and economic constraints in Ontario limit the supply of agricultural and forest residues to the renewable energy industries [14]. On the other hand, energy crops (for example, Miscanthus) are a promising feedstock for biochemical conversion into ethanol and can be cultivated on marginal land without competing with food production $[15,16]$. Kludze et al. - also noted that Miscanthus can be cultivated on the adequate land base of Ontario to meet or surpass numerous viable uses of lignocellulosic biomass [17].

The change in land use patterns significantly affects the mitigate greenhouse gas (GHG) emission from the life cycle (LC) of ethanol $[15,18,19]$. Several studies on the LC of ethanol from Miscanthus mostly focused on bio-refineries, agricultural practices, and indirect land use change [15,20]. Scown et al. [15] studied the LC of ethanol considering two land classes (active land and conservation reserve program (CRP) land which does not produce any agricultural products for a certain period, i.e., 10-15 years). The author noted that indirect land use change and energy credits significantly affect the GHG emissions of the LC of ethanol from Miscanthus. Ethanol produced from the perennial crops was also reported to be environmentally beneficial compared with annual crops [20].

The emission and production costs depend on the feedstock, location, plant sizes, conversion technologies, biomass logistics, and coproduct allocation [14,21-27]. The viability of ethanol is also dependent on the supply of feedstock (agricultural residues) and the possibility of integration with external heat sinks [26]. Several authors noted that the methodology integration (MILP: mixed integer linear programming; Dynamic LCA (life cycle assessment); GIS: geographic information system, and LCA or GCAM: global change assessment model) helps in implementing the local bioenergy energy systems from energy crops and improve their environmental performances [18,28-30]. The economic and environmental performances of the bioenergy system (SNG: synthetic natural gas from wood) were also dependent on the availability of feedstock, plant sizes, and locations [27]. The economic and environmental optima were obtained at a plant capacity of 100-200 MW and 5-40 MW, respectively, 
while the minimum trade-off observed at a plant size of $25 \mathrm{MW}$. Consequently, four scenarios have been established based on the land classes in different locations considering the effect of crop rotation to evaluate the LC of ethanol. This study attempts to identify the potential location for the Miscanthus-based ethanol industry $(20,000 \mathrm{~kL} / \mathrm{year})$ in Ontario, Canada to abate GHG emissions and minimize the production cost of ethanol.

\section{Methodology}

\subsection{Study Area}

There are two major regions in Ontario: Southern and Northern Ontario. The Southern region is further subdivided into four regions (Central, Eastern, Southern, and Western Ontario). In Canada, the land has been grouped into seven classes (Table S1), among which classes 6 and 7 are noted to not be suitable for cultivation. The land suitable for field crops is further classified into two subgroups: prime (classes 1, 2 and 3) and marginal land (classes 4 and 5). Agricultural land in the northern region is not suitable for Miscanthus (Miscanthus $\times$ giganteus) cultivation because of its short growing period (frost-free days are only 100-145 days) excluded from this study [17,31]. The area of land under different classes varies from region to region and scattered throughout the regions (Table S2).

\subsection{System Boundary and Assumptions}

The system boundary of this study is outlined based on the cradle to grave scenario approach (Figure 1). Although all classes of cultivable lands are suitable for Miscanthus, yield, production cost, and net emission from cultivation are varied depending on the land classes, crop rotation, and regions [17,31]. Consequently, four scenarios have been established for various regions (Central, Southern, Western and Eastern Ontario) (Table 1).

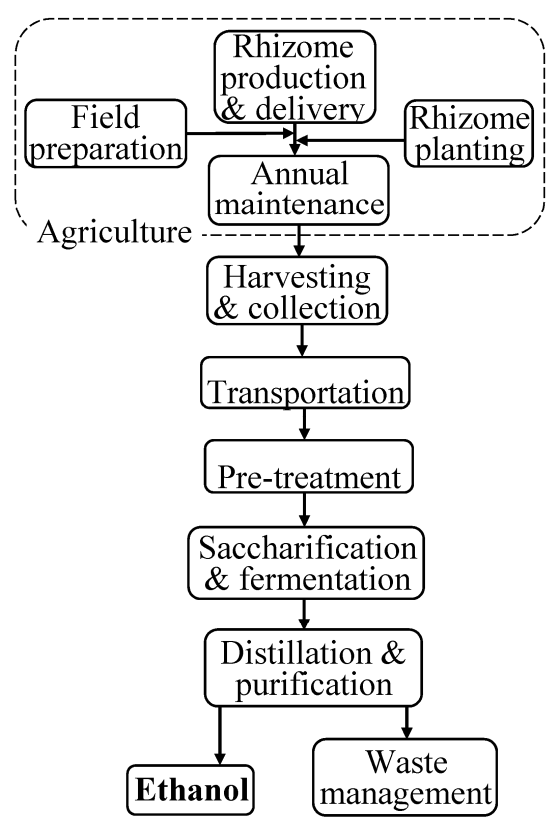

Figure 1. Schematic diagram of the life cycle (LC) of Miscanthus and the system boundary of this study. 
Table 1. Scenarios of this study.

\begin{tabular}{ccccccc}
\hline Scenario & Land class & Soil type & Crop rotation & $\begin{array}{c}\text { Yield, } \\
\text { tDM/ha }\end{array}$ & $\begin{array}{c}\text { Cost, } \\
\text { \$/tDM }\end{array}$ & $\begin{array}{c}* \text { Emission, } \\
\text { kg-CO2e/tDM }\end{array}$ \\
\hline $\mathrm{S}_{1}$ & $1 \& 2$ & Silt loam-clay loom & Corn-soy rotation & 11.14 & 62.63 & -28.58 \\
$\mathrm{~S}_{2}$ & 3 & Sandy-clay & Continuous soybean rotation & 10.03 & 65.67 & -88.77 \\
$\mathrm{~S}_{3}$ & 3 & Sandy-clay & Corn-corn-forage-forage rotation & 10.03 & 65.67 & 167.47 \\
$\mathrm{~S}_{4}$ & $4 \& 5$ & Sandy loam & Long term pasture & 8.35 & 71.50 & 167.67 \\
\hline
\end{tabular}

Sources: Kludze et al., 2013 [17]; Sanscartier et al., 2014 [31]; * net emission from Miscanthus cultivation is estimated considering the carbon dynamics.

Both literature and estimated data have been used. The parameters/process for which data are collected have been reported in the supporting information, including their sources (Table S3). Energy inputs in production of machineries and construction of the ethanol plant are not considered. Also, input in the form of feedstock and labor is not considered. GHG emissions have been estimated in terms of $\mathrm{CO}_{2} \mathrm{e}$ (i.e., global warming potential for a time span of 100 years; IPCC, 2001). The net energy consumption has been estimated by subtracting the recovered energy (from by-product, i.e., lignin) from the total input energy in the process. The net emission is considered to be the difference between input energy-emission and the carbon dynamics (carbon released in the atmosphere from feedsock, i.e., change in carbon due to feedstock cultivation, which is calculated based on the soil organic carbon and carbon content in above- and below-ground biomass) and the amount of emission offset by the by-product. The capacity of the ethanol plant is considered to be $20,000 \mathrm{~kL} / \mathrm{year}$.

\subsection{Transportation}

The transportation distance has been estimated based on a published methodology (Supplementary materials SI-4) and the following assumptions: $6 \mathrm{~m}$ (20 feet) trailer-trucks have been used to transport the harvested and baled Miscanthus to the ethanol processing plant, loading capacity is $75 \%$, moisture content is $15 \%$ in harvested Miscanthus; and the bulk density of baled Miscanthus is $218 \mathrm{~kg} / \mathrm{m}^{3}$ [32].

\subsection{Ethanol Production}

\subsubsection{Pre-Treatment}

The commonly-used Miscanthus pre-treatment methods are ammonia fiber expansion, $\mathrm{NaOH}$ treatment, wet explosion, acid hydrolysis, and liquid hot water (LHW) [33-39]. The alkaline pre-treatment is noted to be more effective and suitable for herbaceous biomass [40]. Therefore, the lime pre-treatment (at $120{ }^{\circ} \mathrm{C}$ for $1 \mathrm{~h}$, solid concentration: $30 \%$ ) is assumed to be given the crushed Miscanthus [41]. The recycle of pretreatment agent (lime) was not considered.

\subsubsection{Fermentation, Distillation and Purification}

Pre-treated Miscanthus slurry is then fermented (SSF) at $33^{\circ} \mathrm{C}$ for $72 \mathrm{~h} \mathrm{[42].} \mathrm{The} \mathrm{solid} \mathrm{content} \mathrm{in} \mathrm{the}$ Miscanthus slurry is considered to be $10 \%$ (wt). Although the enzyme loading is noted to vary from $10 \mathrm{FPU} / \mathrm{g}$-cellu to $20 \mathrm{FPU} / \mathrm{g}$-cellulose in producing ethanol from Miscanthus [33,43], it is assumed to be 
8.04 FPU/g Miscanthus. The ethanol yield is also reported to vary from $0.189 \mathrm{~L} / \mathrm{kg}$ to $0.427 \mathrm{~L} / \mathrm{kg}[39,44-46]$. In this study, ethanol yield is assumed to be $0.305 \mathrm{~L} / \mathrm{kg}$-dry feedstock.

\subsubsection{Waste Management}

The waste stream of lignocellulosic ethanol mainly consists of solids (lignin; hereafter referred to as by-product) and liquid (wastewater). Biogas is produced in anaerobic digestion of the wastewater and the dried lignin is combusted in a boiler for heat recovery. It is assumed that biogas generated in the waste management system offsets the energy consumed in the system and heat recovered from lignin offsets some of the process heat supplied by natural gas. The emission and cost that is credited to recovered heat is ascertained with the emission factor and cost of natural gas.

\subsection{Cost Analysis}

The production cost of ethanol is estimated based on both the fixed- and variable costs. The economic life span of the ethanol plant and the yearly operating period are considered to be 20 years and 350 days, respectively. The interest rate on investment is anticipated to be $3 \%$ and the maintenance cost is $2 \%$ of the plant cost, respectively. The feedstock cost is considered to be about 62.3-71.5\$/tDM depending on the scenarios, which are the breakeven costs of Miscanthus [17].

\section{Results and Discussion}

\subsection{Net Energy Consumption}

The net energy consumption in the LC of ethanol is dependent on the energy inputs in each stage of the LC considered in the system boundary of the study. The shortest and longest transportation distance is found in the case of scenario $\mathrm{S}_{1}$ and $\mathrm{S}_{4}$, respectively, for each location except Central Ontario. The transportation distance is observed to be lower than that of $S_{2}$ and $S_{3}$ for this location (Figure 2). The transportation distance varied from $12.5 \mathrm{~km}$ to $65.2 \mathrm{~km}$ depending on the location and scenarios $\left(\mathrm{S}_{1}\right.$ to $\left.\mathrm{S}_{4}\right)$. It is found to be the shortest for Eastern Ontario and longest for Western Ontario for each scenario compared with other locations.

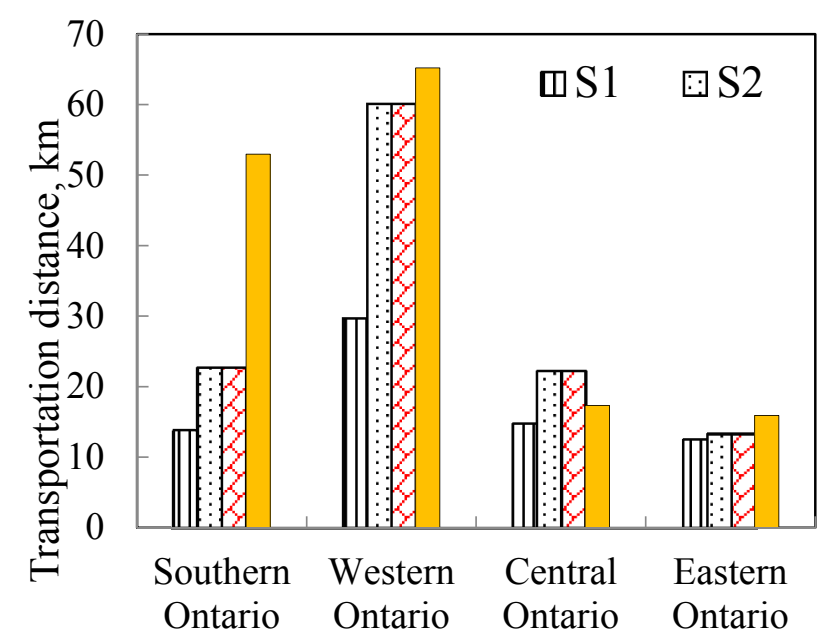

Figure 2. Feedstock transportation distance at different locations in Ontario. 
The difference in transportation distance among the scenarios resulted in a slight variation in transportation energy consumption. Pretreatment has emerged as the main contributor, followed by distillation, enzyme, SSF, yeast, feedstock, and transportation for each scenario (Figure 3a). It seems that the energy recovery from by-products plays an important role in the net energy consumption in the LC of ethanol. The by-product offsets a part of the energy consumed in the process, which has a robust contribution to the net energy consumption for all scenarios. The net energy consumption varied from 13.0 $\mathrm{MJ} / \mathrm{L}$ to $13.4 \mathrm{MJ} / \mathrm{L}$. It seems to be sensitive to co-product allocation and assumptions of the study $[24,47]$. Thus, the net energy consumption found to vary from other studies because a different feedstock has been used and different assumptions were made in those studies [22-24,48]. The net energy consumption may vary if a different Miscanthus variety, cultivation, and pre-treatment methods were adopted. Similar to the transportation distance, the energy consumption is found to be the lowest for $\mathrm{S}_{1}$ and highest to $\mathrm{S}_{4}$ among the scenarios; however a slight variation was observed among the processing plant locations (Figure $3 b$ ).

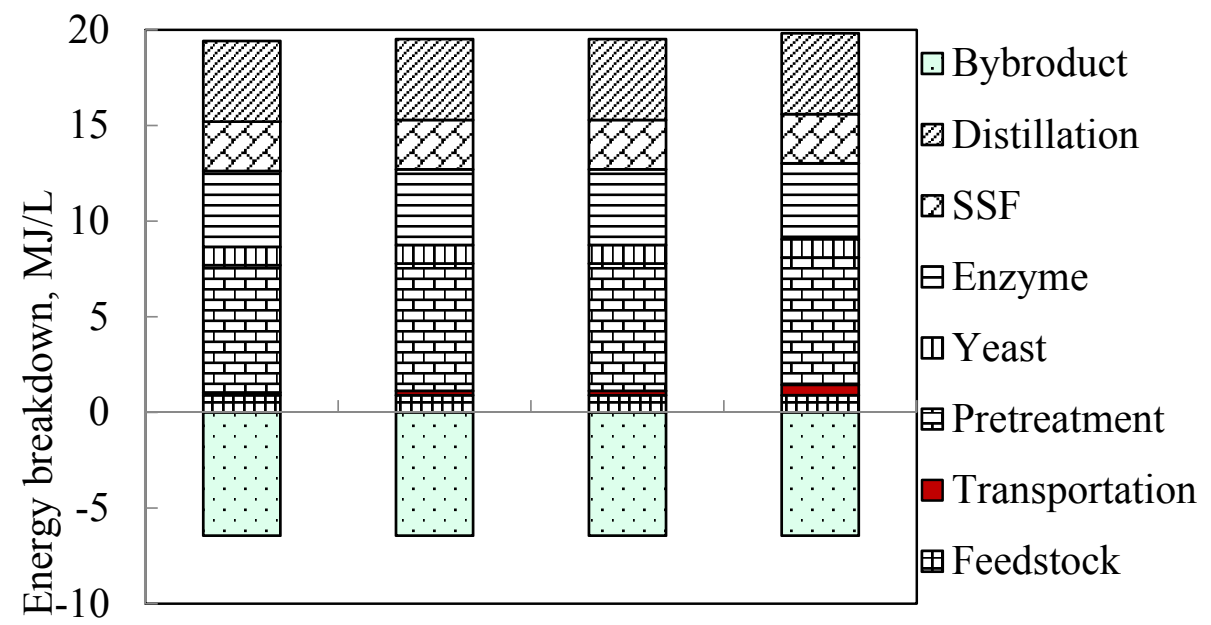

(a)

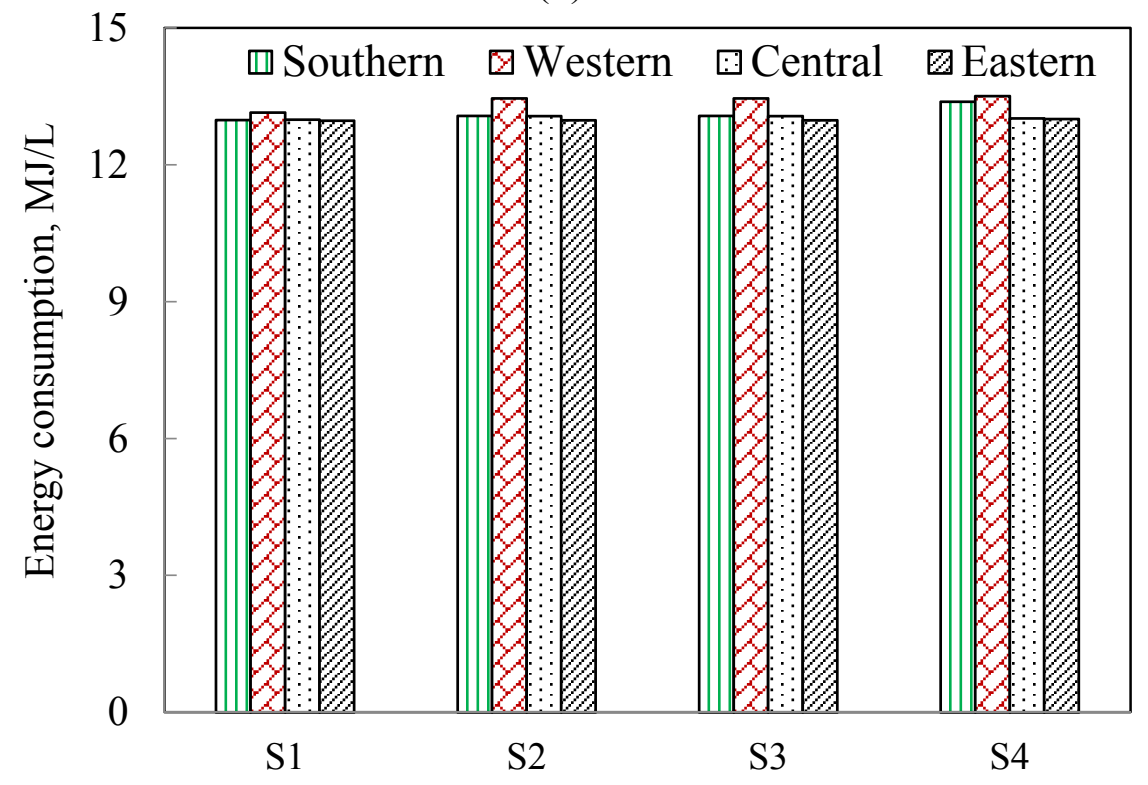

(b)

Figure 3. (a) Energy breakdown for different scenarios (Southern Ontario); and (b) net energy consumption at different location in Ontario. 


\subsection{Greenhouse Gas (GHG) Emission ( $\left.\mathrm{CO}_{2} \mathrm{e}\right)$}

The emissions were directly related to energy and resource consumption at different stages except feedstock because carbon dynamics offset a major part in the case of feedstock. The pre-treatment process has emerged as the main contributor followed by distillation, enzyme, SSF, yeast, and transportation, except $\mathrm{S}_{3}$ and $\mathrm{S}_{4}$ where feedstock has emerged as the main contributor because of the positive carbon dynamics (i.e., carbon released to the atmosphere) of the feedstock (Figure 4). On the other hand, negative carbon dynamics are observed in the case of $\mathrm{S}_{1}$ and $\mathrm{S}_{3}$. Consequently, emissions from feedstock are found to be $-0.09,-0.29,0.55$, and $0.55 \mathrm{~kg} / \mathrm{L}$ for $\mathrm{S}_{1}, \mathrm{~S}_{2}, \mathrm{~S}_{3}$, and $\mathrm{S}_{4}$ (marginal land), respectively. The net emission from transportation varied marginally among the scenarios and locations because of the variation in distance. The carbon dynamics are noted to be dependent on the land classes, crop replacement/rotation, and biomass yield [17,31]. Consequently, the net emission would vary if different crop displacement or crop rotations were considered. The emission from feedstock was observed to be the highest in the case of $\mathrm{S}_{4}$ and the lowest for $\mathrm{S}_{1}$. These variations indicate that carbon dynamics were not only dependent on the land types and regions of cultivation, but also on the crop rotation. Although the same land class has been considered for $S_{2}$ and $S_{3}$, the carbon dynamics varied, which might have been because different crop displacements were assumed. The net emission from the LC of ethanol is estimated to be $0.45-1.32 \mathrm{~kg} / \mathrm{L}$ depending on the scenarios and processing plant locations, which seems to be mainly dependent on the carbon dynamics and the emission offsets by the by-product. The net emission was perceived to be within the range of the emissions reported in other studies on lignocellulosic ethanol $[13,15,24]$. The results also confirmed that these variations might not only be due to the type of land, but also the region and crop rotation, because various crop rotations were considered for different scenarios. The net emission was found to be the lowest in the case of $\mathrm{S}_{2}$ in a plant located in the Eastern Ontario and the highest in the case of $\mathrm{S}_{4}$, located at Western Ontario (Figure 5). These values indicate that environmental advantages can be achieved from Miscanthus-based ethanol at all locations that were considered in this study, even if Miscanthus was cultivated on marginal land. It is important to mention that the net emissions may vary if different crop displacement are considered.

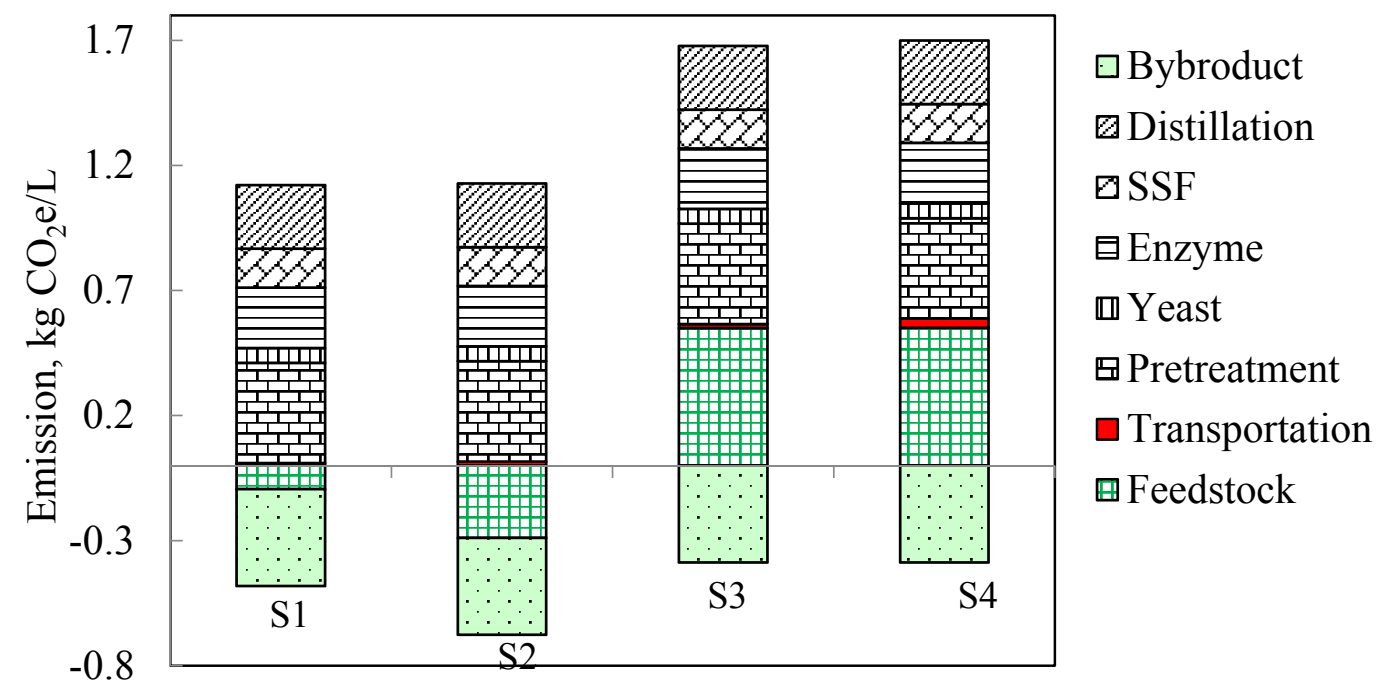

Figure 4. Emission breakdown of the LC of ethanol (Southern Ontario). 


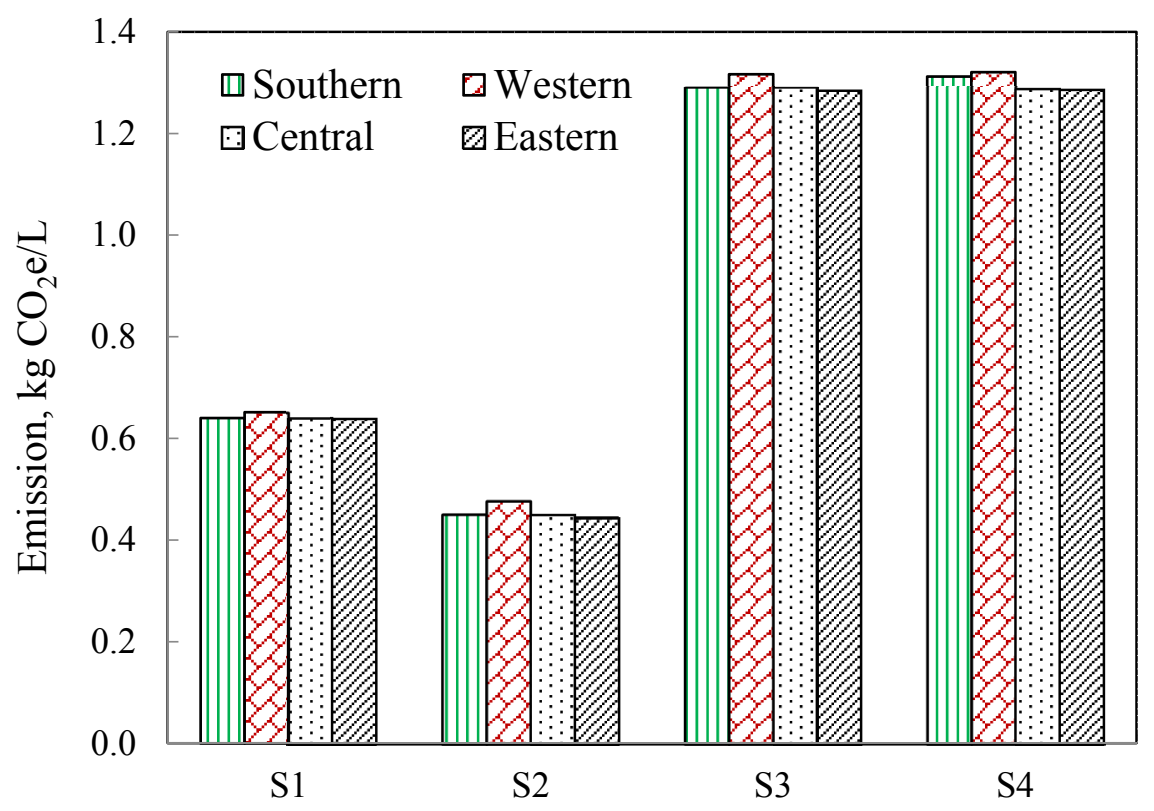

Figure 5. Net emission at different locations in Ontario.

\subsection{Production Cost}

The production cost breakdown depicts that the fixed, feedstock, and transportation costs varied from $0.246 \$ / \mathrm{L}$ to $0.247 \$ / \mathrm{L}, 0.205 \$ / \mathrm{L}$ to $0.235 \$ / \mathrm{L}$, and $0.005 \$ / \mathrm{L}$ to $0.020 \$ / \mathrm{L}$, respectively, liable on the scenarios and the location of the processing plant. A slight variation in fixed and feedstock costs were caused by the variation in feedstock production cost among the scenarios. Similarly, the variation in transportation distance influenced the transportation cost. However, the cost of other stages of the LC of ethanol remains same because the same technologies are applied in various scenarios. Although, there was a slight variation in fixed, feedstock, and transportation costs among the scenarios, the fixed cost has emerged as the main contributor in the net production cost followed by feedstock, pre-treatment, distillation, SSF, yeast, and transportation for all locations (Figure 6).

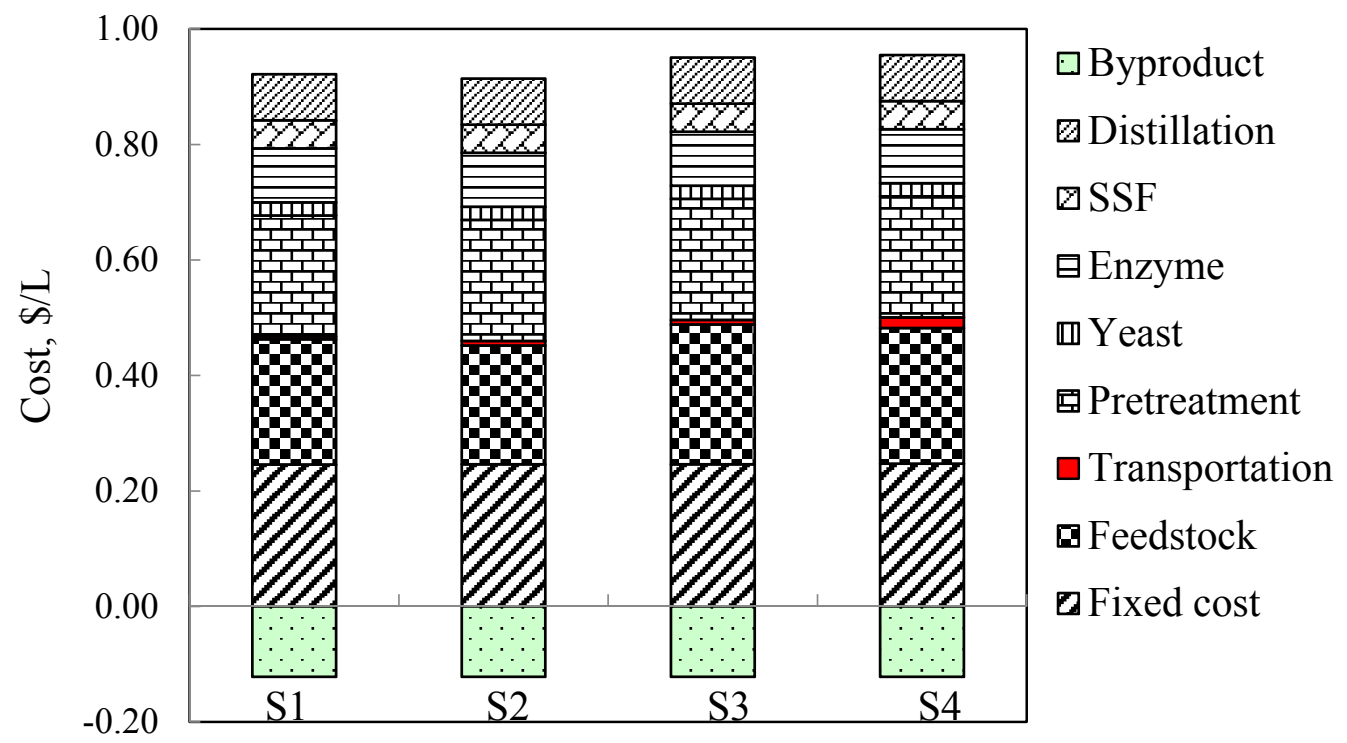

Figure 6. Cost breakdown of the LC of ethanol (Southern Ontario). 
The estimated net production cost varied from $0.79 \$ / \mathrm{L}$ to $0.84 \$ / \mathrm{L}$ depending on the scenarios and the location of the processing plant. Although a slight variation was observed among the scenarios and location, the net production cost is found to be the lowest for $\mathrm{S}_{2}$ and the plant location in Eastern Ontario, and the highest for $\mathrm{S}_{4}$ and the plant location in Western Ontario for the variation in fixed, feedstock, and transportation costs among the scenarios (Figure 7). The breakeven feedstock cost is considered for the production cost estimation, which may vary depending on the biomass logistics and farmers' profit margins. Consequently the net production cost may also vary if the feedstock cost is variable. The production cost is dependent on the conversion technology, enzyme loading, feedstock, allocation methods, and plant sizes [21,24]; thus, production costs may vary, if different conversion methods, allocation, and plant sizes are considered. Although the cost of lignocellulosic ethanol is reported to be vary widely $[22,24,49-52]$, the production costs estimated in this study are found to be reasonable and comparable with other studies.

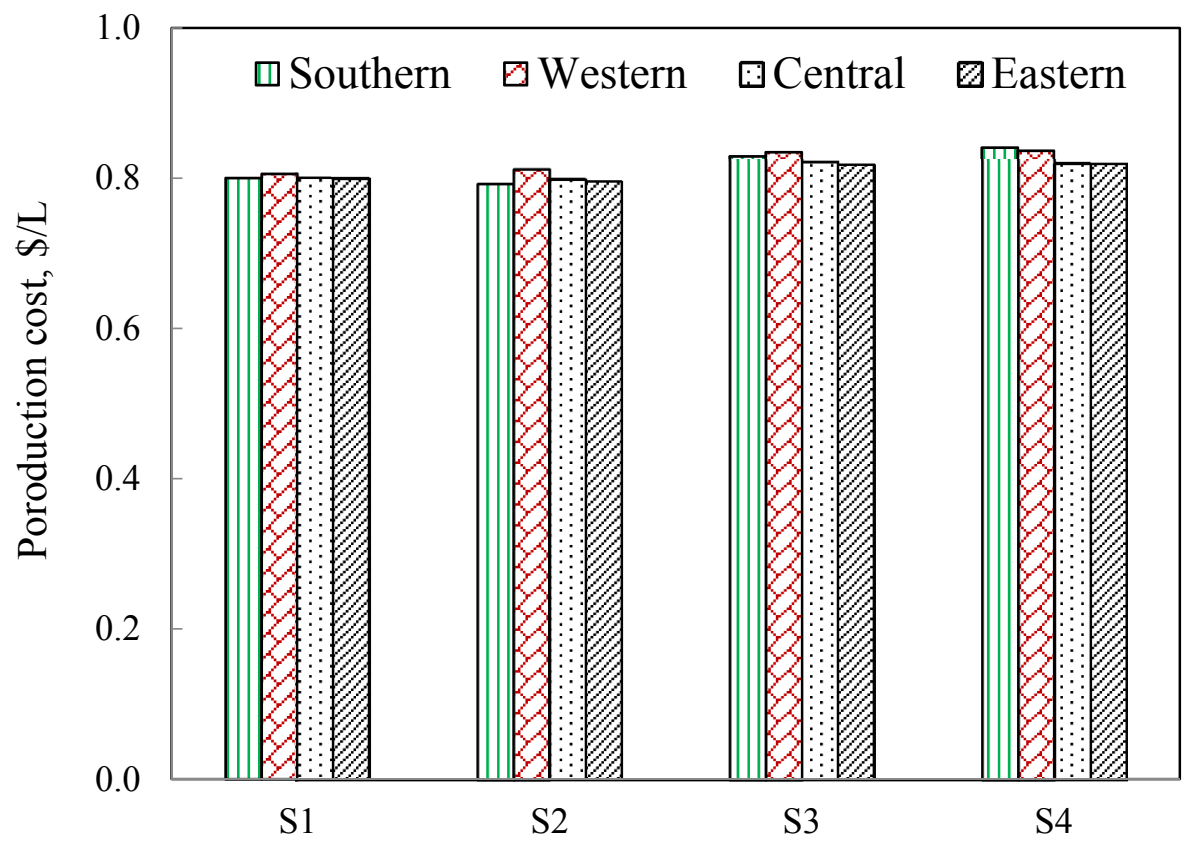

Figure 7. Net production cost at different locations in Ontario.

\subsection{Sensitivity Analysis}

The LCA results of lignocellulosic ethanol are reported to be more sensitive to the changes in parameters related to the biomass and ethanol yield [23,49]. A wide variation in ethanol yield from Miscanthus [39,44-46], feedstock, and enzyme cost are also stated [50,53]. The potential hotspots are identified to be feedstock, pre-treatment, and fixed cost in case of energy consumption, emission, and production cost, respectively. This study indicates that the by-product has a robust contribution in the LC of lignocellulosic ethanol. The breakeven feedstock cost is used to estimate the production cost, which may depend on the biomass logistics, farmer's profit margin, and renewable energy policy. Therefore, the effect of plant capacity (which is mainly sensitive to fixed cost), ethanol yield, and feedstock cost on the production cost have been determined. The effect of the variation $( \pm 20 \%)$ of parameters on net emission and production has also been worked out for $\mathrm{S}_{4}$. 
It is confirmed that the ethanol plant capacity affects the production cost and emission (Figure 8). The production cost reduced with an expansion in plant capacity; however, the emissions increased because the higher feedstock demand resulted in a longer transportation distance. The production cost is found to be reduced from $1.0 \$ / \mathrm{L}$ to $0.67 \$ / \mathrm{L}$ and emissions increased from $1.29 \mathrm{~kg} \mathrm{CO} 2 \mathrm{e} / \mathrm{L}$ to $1.37 \mathrm{~kg} \mathrm{CO} 2 \mathrm{e} / \mathrm{L}$ for the increase of plant capacity from $5300 \mathrm{ML} / \mathrm{y}$ to $300 \mathrm{ML} / \mathrm{y}$. Increasing ethanol and biomass yield may help in reducing biomass demand and the transportation distance. Figure 9 depicts that the cost of ethanol not only dependent on the cost of feedstock, but also on the ethanol yield. Although there is a slight variation in the case of fixed costs because of different feedstock demand, this study also depicts that the higher the ethanol yield, the lower the production cost. Higher ethanol yield not only reduces the feedstock demand and the transportation distance, but also has a positive impact on each stage of the LC of lignocellulosic ethanol.

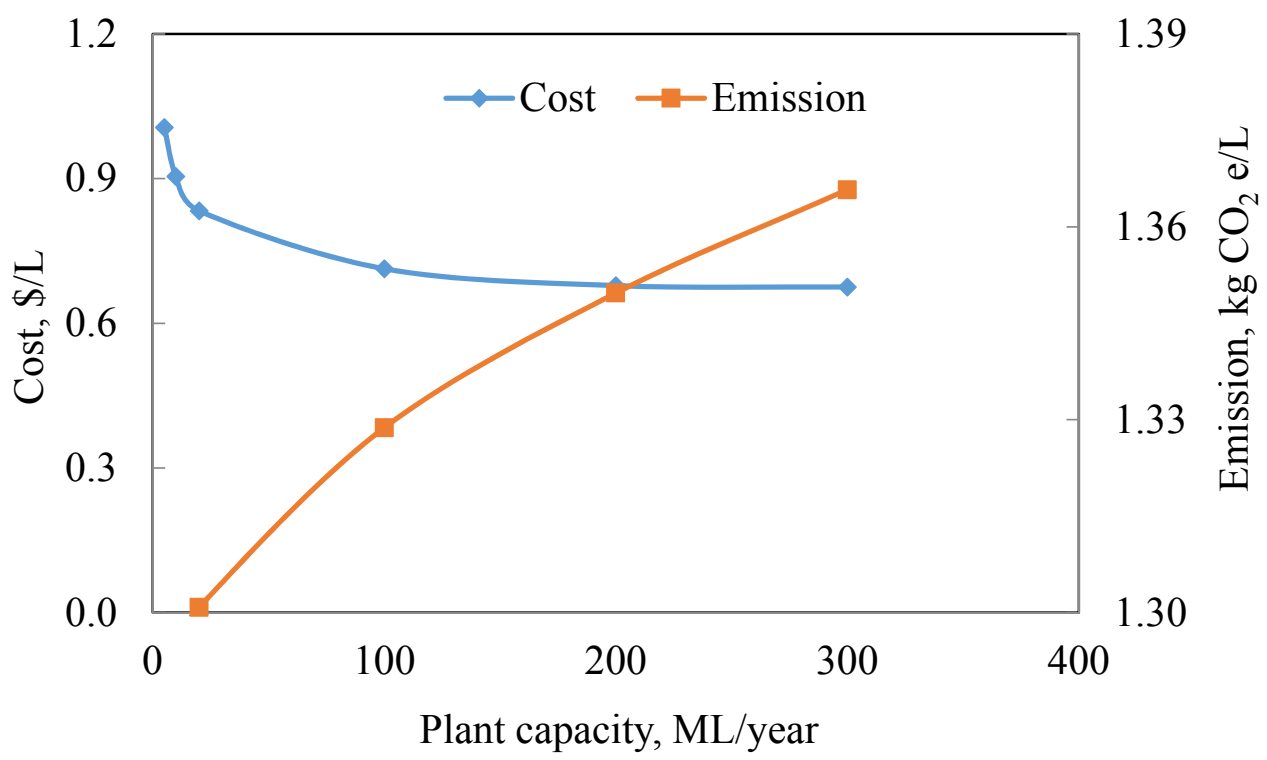

Figure 8. Effect of ethanol plant capacity on production cost and emission.

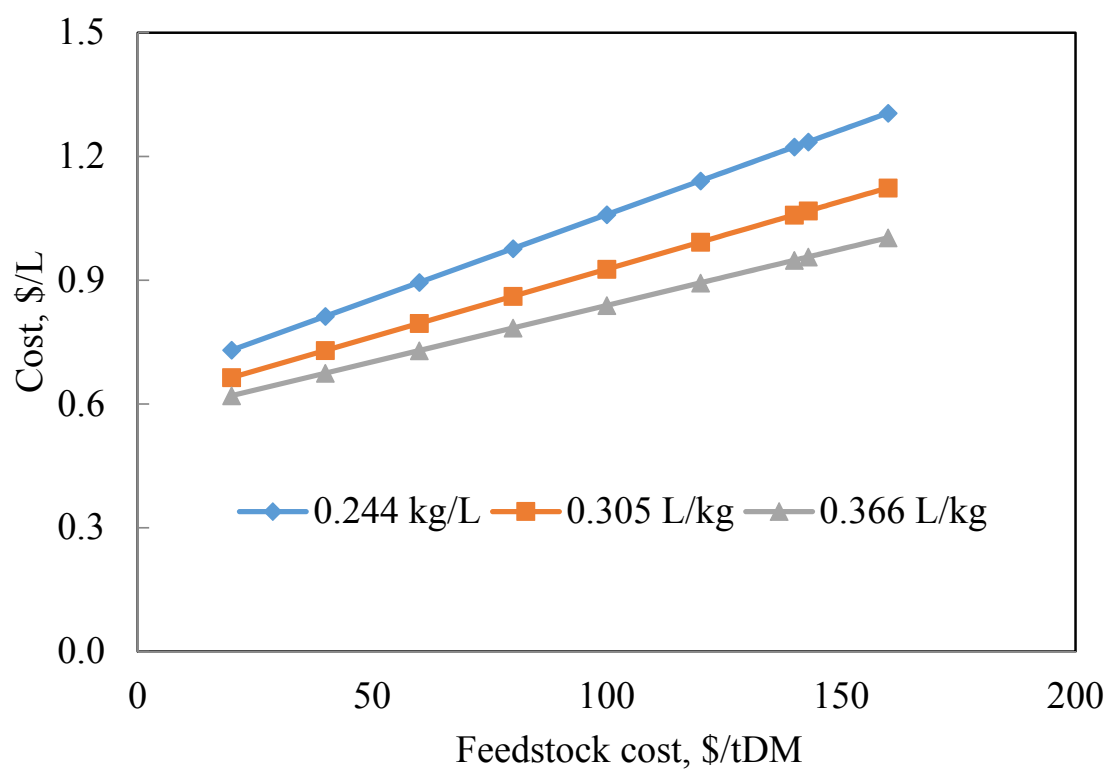

Figure 9. Effect of feedstock cost and ethanol yield on production cost and emission. 
The net emission and production cost varied from about $1.2 \mathrm{~kg}-\mathrm{CO}_{2} \mathrm{e} / \mathrm{L}$ to $1.5 \mathrm{~kg}-\mathrm{CO}_{2} \mathrm{e} / \mathrm{L}$ and $0.8 \$ / \mathrm{L}$ to $1.0 \$ / \mathrm{L}$, respectively, depending on the severity of the variation (Figure 10). These figures also depict that ethanol yield has a more robust impact on both net emission and production cost than others. Although higher ethanol yield reduced energy recovery from the by-product and decreased the opportunity for emission and cost offsetting because of the lower amount of by-product (lignin) recovery from the system, the net emission and production cost observed to be reduced. The production cost can further be reduced if agri-industrial and environmental policies are enacted to support the Miscanthus-based ethanol industry, especially for Miscanthus grown on the marginal land and used for ethanol. It is important to note that net emissions from the LC of ethanol from Miscanthus not only depended on the land classes, but also on the crop displacement ( $\mathrm{S}_{2}$ and $\mathrm{S}_{3}$ where the same land classes are used).

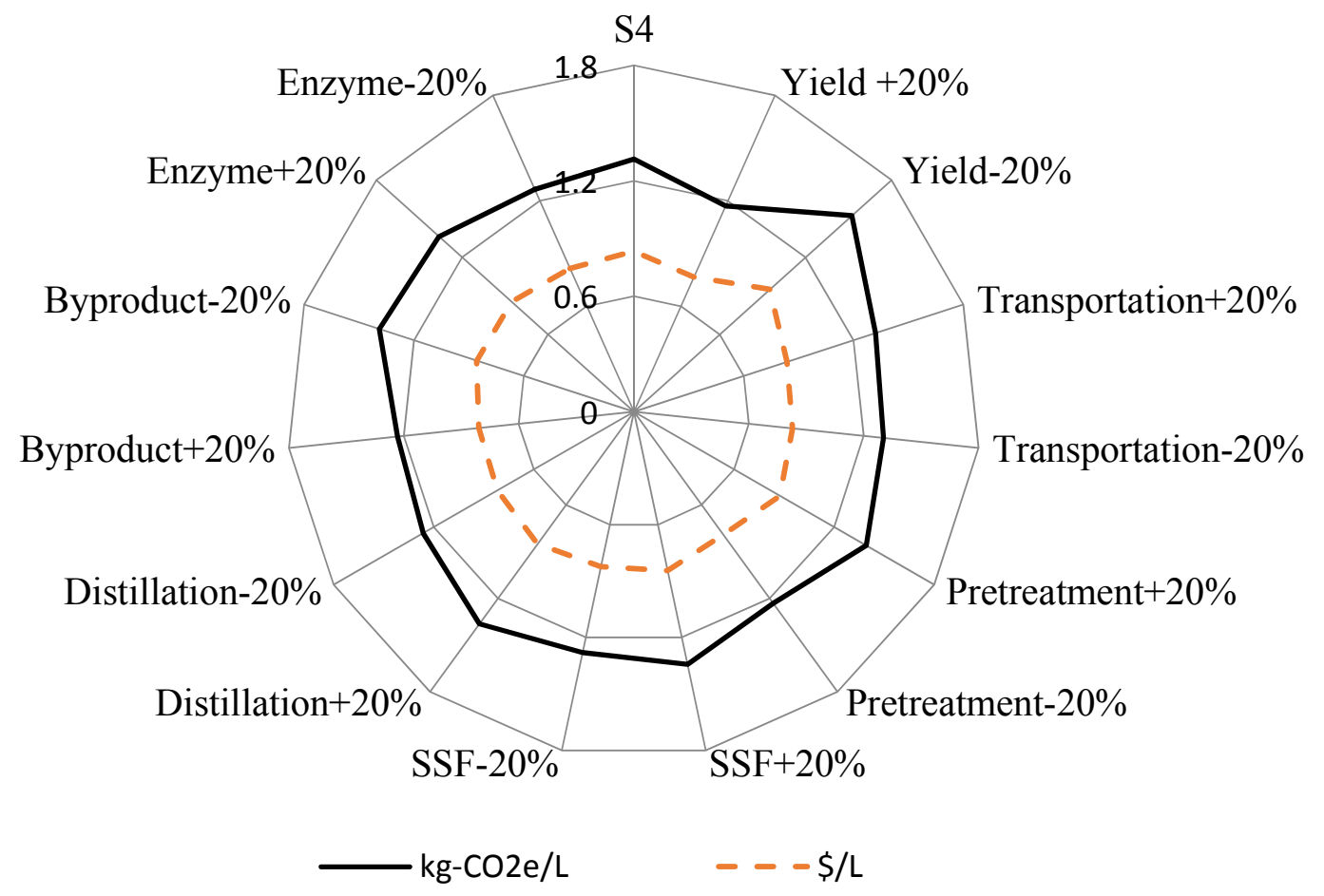

Figure 10. Effect of the variation of different parameters on net emission.

Eastern Ontario has emerged to be the best location for the Miscanthus-based ethanol industry among the locations studied in Ontario, which seems to be environmentally and economically viable. Bennett et al. [54] reported that genetically modified (GM) crops can serve various purposes, such as improving yield, increasing the share of useful components or decreasing the need for chemical fertilizers or water, and improves farm income. Therefore, net emission and production costs of ethanol from Miscanthus may further be reduced if GM Miscanthus is considered and promoted for the ethanol industry, improve farm income and rural economy, and future energy security. This study reveals that Miscanthus is a promising feedstock for lignocellulosic-based ethanol, even if it is grown on the marginal land in Ontario and may avoid any competition with food crops for prime land helping Ontario improve food and energy security. However, the Miscanthus-based ethanol industry might need to be regulated to avoid any sort of competition with food crops for higher quality land and their rebound effects; improve farm income and rural economy. 


\section{Conclusions}

This study identifies the potential locations for Miscanthus-based ethanol industry in Ontario, Canada and determines the environmental and economic viability of Miscanthus-based ethanol. A slight variation was observed in the case of net energy consumption and production cost; however, the variation emerged to be robust in the case of net emissions, where carbon dynamics play a key role. The scenario $\mathrm{S}_{2}$ is found to be the best option to abate GHG emissions, which indicates that GHG emissions are dependent not only on the land classes but also on the crop displacement. The results indicate that the Miscanthus-based ethanol industries are economically and environmentally viable for all scenarios and locations in Ontario, even if Miscanthus is grown on marginal land. Eastern Ontario appeared to be the best option for the Miscanthus-based ethanol industry in Ontario. However, the Miscanthus-based ethanol industry might need to be regulated to avoid any sort of competition with food crops for higher quality land and their rebound effects; improving farm income and rural economy. This study may help the stakeholders in their decision-making processes, meeting the ethanol demand, and achieving the GHG emissions target of Canada.

\section{Supplementary Materials}

Supplementary materials can be accessed at: http://www.mdpi.com/1996-1073/8/9/9266/s1.

\section{Acknowledgments}

The authors are grateful to the NSERC Discovery (Grant No. 400495), and Ontario Ministry of Agriculture, Food and Rural Affairs (OMAFRA, Grant No. 200474) for financial support in this study. The authors also thankful to Jamie Minaret for his assistance in the proofreading of this manuscript.

\section{Author Contributions}

Poritosh Roy conducted the study and he was supervised by Animesh Dutta and Bill Deen.

\section{Conflicts of Interest}

The authors declare no conflict of interest.

\section{References}

1. Natural Resource Canada (NRC). Energy Use Data Handbook Tables (Canada) - Transportation Sector. Available online: http://data.gc.ca/data/dataset/cec843a2-b8cb-4168-81f1-e1ced9daf5da (accessed on 28 September 2013).

2. Environment Canada. Renewable Fuels Regulations. Available online: http://www.ec.gc.ca/ energie-energy/default.asp?lang=En\&n=0AA71ED2-1 (accessed on 2 October 2013).

3. Biofuelnet. An Overview of Canadian Federal Biofuels Programs. Available online: http://www.biofuelnet.ca/2013/10/03/an-overview-of-canadian-federal-biofuels-programs/ (accessed on 21 December 2014). 
4. Winchester, N.; Reilly, J.M. The Contribution of Biomass to Emissions Mitigation under a Global Climate Policy; Technical Report for MIT Joint Program on the Science and Policy of Global Change: Cambridge, MA, USA, 2015.

5. Liew F.M.; Köpke, M.; Simpson, S.D. Gas fermentation for commercial biofuels production. In Liquid, Gaseous and Solid Biofuels-Conversion Techniques; Fang, Z., Ed.; InTech: Rijeka, Croatia, 2013.

6. Mueller, S.A.; Anderson, J.E.; Wallington, T.J. Impact of biofuel production and other supply and demand factors on food price increases in 2008. Biomass Bioenergy 2011, 5, 1623-1632.

7. Hahn-Hägerdal, B.; Galbe, M.; Gorwa-Grauslund, M.F.; Lidén, G.; Zacchi, G. Bio-ethanol—The fuel of tomorrow from the residues of today. Trends Biotechnol. 2006, 24, 549-556.

8. Sanchez, O.J.; Cardona, C.A. Trends in biotechnological production of fuel ethanol from different feedstocks. Bioresour. Technol. 2008, 99, 5270-5295.

9. Akhurst, M.; Kalas, N.; Woods, J. Meta-analysis of biomass potentials for biofuel production. Sci. Insights Biofuel Policy 2011, 2, 1-9.

10. Sims, R.E. Bioenergy Options for a Cleaner Environment: In Developed and Developing Countries: in Developed and Developing Countries; Elsevier: Amsterdam, The Netherlands, 2003.

11. World Energy Outlook 2010; International Energy Agency (IEA): London, UK, 2010.

12. Cai, X.; Zhang, X.; Wang, D. Land availability for biofuel production. Environ. Sci. Technol. 2011, $45,334-339$.

13. Weiser, C.; Zeller, V.; Reinicke, F.; Wagner, B.; Majer, S.; Vetter, A.; Thraen, D. Integrated assessment of sustainable cereal straw potential and different straw-based energy applications in Germany. Appl. Energy 2014, 114, 749-762.

14. Kludze, H.; Deen, B.; Weersink, A.; van Acker, R.; Janovicek, K.; de Laporte, A. Assessment of the Availability of Agricultural Biomass for Heat and Energy Production in Ontario; Technical Report for Ontario Ministry of Agriculture, Food and Rural Affairs: Toronto, ON, Canada, 2010.

15. Scown, C.D.; Nazaroff, W.W.; Mishra, U.; Strogen, B.; Lobscheid, A.B.; Masanet, E.; McKone, T.E. Lifecycle greenhouse gas implications of US national scenarios for cellulosic ethanol production. Environ. Res. Lett. 2012, 7, doi:10.1088/1748-9326/7/1/014011.

16. Somerville, C.; Youngs, H.; Taylor, C.; Davis, S.C.; Long, S.P. Feedstocks for lignocellulosic biofuels. Science 2010, 329, 790-792.

17. Kludze, H.; Deen, B.; Weersink, A.; van Acker, R.; Janovicek, K.; De Laporte, A. Impact of land classification on potential warm season grass biomass production in Ontario, Canada. Can. J. Plant Sci. 2013, 93, 249-260.

18. Wise, M.; Dooley, J.; Luckow, P.; Calvin, K.; Kyle, P. Agriculture, land use, energy and carbon emission impacts of global biofuel mandates to mid-century. Appl. Energy 2014, 114, 763-773.

19. Searchinger, T.; Heimlich, R.; Houghton, R.A.; Dong, F.; Elobeid, A.; Fabiosa, J.; Tokgoz, S.; Hayes, D.; Yu, T.H. Use of US croplands for biofuels increases greenhouse gases through emissions from land-use change. Science 2008, 319, 1238-1240.

20. Fazio, S.; Monti, A. Life cycle assessment of different bioenergy production systems including perennial and annual crops. Biomass Bioenergy 2011, 35, 4868-4878.

21. Gnansounou, E.; Dauriat, A. Techno-economic analysis of lignocellulosic ethanol: A review. Bioresour. Technol. 2010, 101, 4980-4991. 
22. Roy, P.; Orikasa, T.; Tokuyasu, K.; Nakamura, N.; Shiina, T. Evaluation of the life cycle of bioethanol produced from rice straws. Bioresour. Technol. 2012, 110, 239-244.

23. Roy, P.; Tokuyasu, K.; Orikasa, T.; Nakamura, N.; Shiina, T. A techno-economic and environmental evaluation of the life cycle of bioethanol produced from rice straw by RT-CaCCO process. Biomass Bioenergy 2012, 37, 188-195.

24. Roy, P.; Dutta, A. Life cycle assessment of ethanol produced from wheat straw. J. Biobased Mater. Bioenergy 2012, 6, 276-282.

25. Nguyen, T.L.T.; Hermansen, J.E. System expansion for handling co-products in LCA of sugar cane bio-energy systems: GHG consequences of using molasses for ethanol production. Appl. Energy 2012, 89, 254-261.

26. Ekman, A.; Wallberg, O.; Joelsson, E.; Börjesson, P. Possibilities for sustainable biorefineries based on agricultural residues-A case study of potential straw-based ethanol production in Sweden. Appl. Energy 2013, 102, 299-308.

27. Steubing, B.; Ballmer, I.; Gassner, M.; Gerber, L.; Pampuri, L.; Bischof, S.; Oliver, T.; Zah, R. Identifying environmentally and economically optimal bioenergy plant sizes and locations: A spatial model of wood-based SNG value chains. Renew. Energy 2014, 61, 57-68.

28. Liu, Z.; Qiu, T.; Chen, B. A study of the LCA based biofuel supply chain multi-objective optimization model with multi-conversion paths in China. Appl. Energy 2014, 126, 221-234.

29. Yang, J.; Chen, B. Global warming impact assessment of a crop residue gasification project-A dynamic LCA perspective. Appl. Energy 2014, 122, 269-279.

30. Gasol, C.M.; Gabarrell, X.; Rigola, M.; González-García, S.; Rieradevall, J. Environmental assessment (LCA) and spatial modelling (GIS) of energy crop implementation on local scale. Biomass Bioenergy 2011, 35, 2975-2985.

31. Sanscartier, D.; Deen, B.; Dias, G.; MacLean, H.L.; Dadfar, H.; McDonald, I.; Kludze, H. Implications of land class and environmental factors on life cycle GHG emissions of Miscanthus as a bioenergy feedstock. GCB Bioenergy 2014, 6, 401-413.

32. Vyn, R.J.; Virani, T.; Deen, B. Examining the economic feasibility of miscanthus in Ontario: An application to the greenhouse industry. Energy Policy 2012, 50, 669-676.

33. Brosse, N.; Sannigrahi, P.; Ragauskas, A. Pretreatment of Miscanthus $\times$ giganteus using the ethanol organosolv process for ethanol production. Ind. Eng. Chem. Res. 2009, 48, 8328-8334.

34. Sørensen, A.; Teller, P.J.; Hilstrøm, T.; Ahring, B.K. Hydrolysis of Miscanthus for bioethanol production using dilute acid presoaking combined with wet explosion pre-treatment and enzymatic treatment. Bioresour. Technol. 2008, 99, 6602-6607.

35. Murnen, H.K.; Balan, V.; Chundawat, S.P.; Bals, B.; Sousa, L.D.C.; Dale, B.E. Optimization of ammonia fiber expansion (AFEX) pretreatment and enzymatic hydrolysis of Miscanthus $\times$ giganteus to fermentable sugars. Biotechnol. Prog. 2007, 23, 846-850.

36. Han, M.; Kim, Y.; Koo, B.C.; Choi, G.W. Bioethanol production by Miscanthus as a lignocellulosic biomass: Focus on high efficiency conversion to glucose and ethanol. Bioresources 2011, 6, 1939-1953.

37. Vanderghem, C.; Brostaux, Y.; Jacquet, N.; Blecker, C.; Paquot, M. Optimization of formic/acetic acid delignification of Miscanthus $\times$ giganteus for enzymatic hydrolysis using response surface methodology. Ind. Crops Prod. 2012, 35, 280-286. 
38. Khullar, E.; Dien, B.S.; Rausch, K.D.; Tumbleson, M.E.; Singh, V. Effect of particle size on enzymatic hydrolysis of pretreated Miscanthus. Ind. Crops Prod. 2013, 44, 11-17.

39. Li, H.Q.; Li, C.L.; Sang, T.; Xu, J. Pretreatment on Miscanthus lutarioriparious by liquid hot water for efficient ethanol production. Biotechnol. Biofuels 2013, 6, doi:10.1186/1754-6834-6-76.

40. Chang, V.S.; Nagwani, M.; Kim, C.H.; Holtzapple, M.T. Oxidative lime pretreatment of high-lignin biomass. Appl. Biochem. Biotechnol. 2001, 94, 1-28.

41. Shiroma, R.; Park, J.Y.; Al-Haq, M.I.; Arakane, M.; Ike, M.; Tokuyasu, K. RT-CaCCO process: An improved $\mathrm{CaCCO}$ process for rice straw by its incorporation with a step of lime pretreatment at room temperature. Bioresour. Technol. 2011, 102, 2943-2949.

42. Junqueira, T.L.; Dias, M.O.; Maciel, M.R.; Maciel Filho, R.; Rossell, C.E.; Atala, D.I. Simulation and optimization of the continuous vacuum extractive fermentation for bioethanol production and evaluation of the influence on distillation process. Comput. Aided Chem. Eng. 2009, 26, 827-832.

43. Gregg, D.J.; Saddler, J.N. Factors affecting cellulose hydrolysis and the potential of enzyme recycle to enhance the efficiency of an integrated wood to ethanol process. Biotechnol. Bioeng. 1996, 51, 375-383.

44. Mansfield, B.K.; Alton, A.J.; Andrews, S.H.; Bownas, J.L.; Casey, D.; Martin, S.A.; Wyrick, J.M. Breaking the Biological Barriers to Cellulosic Ethanol: A Joint Research Agenda; Technocal Report for Oak Ridge National Laboratory: Oak Ridge, TN, USA, 2006.

45. Nilsson, H. Flexibility in Wheat Bioethanol Plants-Conditions for Conversion to Lignocellulosic Feedstock. Available online: http://www.chemeng.lth.se/exjobb/E471.pdf (accessed on 12 October 2014).

46. Zhang, T.; Wyman, C.E.; Jakob, K.; Yang, B. Rapid selection and identification of Miscanthus genotypes with enhanced glucan and xylan yields from hydrothermal pretreatment followed by enzymatic hydrolysis. Biotechnol. Biofuels 2012, 5, doi:10.1186/1754-6834-5-56.

47. Pimentel, D.; Patzek, T.W. Ethanol production using corn, switchgrass, and wood; biodiesel production using soybean and sunflower. Nat. Resour. Res. 2005, 14, 65-76.

48. Kim, S.; Dale, B.E. Life cycle assessment of various cropping systems utilized for producing biofuels: Bioethanol and biodiesel. Biomass Bioenergy 2005, 29, 426-439.

49. Roy, P.; Dutta, A. Life cycle assessment of ethanol derived from sawdust. Bioresour. Technol. 2013, 150, 407-411.

50. Dutta, A.; Bain, R.L.; Biddy, M.J. Techno-economics of the production of mixed alcohols from lignocellulosic biomass via high-temperature gasification. Environ. Prog. Sustain. Energy 2010, 29, 163-174.

51. Klein-Marcuschamer, D.; Oleskowicz-Popiel, P.; Simmons, B.A.; Blanch, H.W. Technoeconomic analysis of biofuels: A wiki-based platform for lignocellulosic biorefineries. Biomass Bioenergy 2010, 34, 1914-1921.

52. Kumar, D.; Murthy, G.S. Impact of pretreatment and downstream processing technologies on economics and energy in cellulosic ethanol production. Biotechnol. Biofuels 2011, 4, doi:10.1186/1754-6834-4-27.

53. Barta, Z.; Reczey, K.; Zacchi, G. Techno-economic evaluation of stillage treatment with anaerobic digestion in a softwood-to-ethanol process. Biotechnol. Biofuels 2010, 3, doi:10.1186/1754-6834-3-21. 
54. Bennett, R.; Phipps, R.; Strange, A.; Grey, P. Environmental and human health impacts of growing genetically modified herbicide-tolerant sugar beet: A life-cycle assessment. Plant Biotechnol. J. 2004, 2, 273-278.

55. Wikipedia. Available online: https://en.wikipedia.org/wiki (accessed on 14 May 2013).

56. Asano, K.; Minowa, T. An Analysis of Bioethanol Production Costs and $\mathrm{CO}_{2}$ Reduction Costs in Japan. J. Jpn Inst. Energy, 2007, 86, 957-963. (In Japanese)

57. Wooley, R.; Ruth, M.; Sheehan, J.; Ibsen, K.; Majdeski, H.; Galvez, A. Lignocellulosic Biomass to Ethanol Process Design and Economics Utilizing Co-Current Dilute Acid Prehydrolysis and Enzymatic Hydrolysis Current and Futuristic Scenarios; Technical Report for National Renewable Energy Lab: Golden, CO, USA, 1999.

58. Dias, M.O.; Junqueira, T.L.; Filho, R.; Maciel, M.R.; Rossell, C.E. Anhydrous bioethanol production using bioglycerol-Simulation of extractive distillation processes. Comput. Aided Chem. Eng. 2009, 26, 519-524.

59. Mani, S.; Sokhansanj, S.; Tagore, S.; Turhollow, A.F. Techno-economic analysis of using corn stover to supply heat and power to a corn ethanol plant-Part 2: Cost of heat and power generation systems. Biomass Bioenergy 2010, 34, 356-364.

60. Huang, H.J.; Ramaswamy, S.; Al-Dajani, W.; Tschirner, U.; Cairncross, R.A. Effect of biomass species and plant size on cellulosic ethanol: A comparative process and economic analysis. Biomass Bioenergy 2009, 33, 234-246.

61. Sokhansanj, S.; Turhollow, A.F. Baseline cost for corn stover collection. Appl. Eng. Agric. 2002, $18,525-532$.

(C) 2015 by the authors; licensee MDPI, Basel, Switzerland. This article is an open access article distributed under the terms and conditions of the Creative Commons Attribution license (http://creativecommons.org/licenses/by/4.0/). 